\title{
FENOMENA KURS RUPIAH SEBELUM DAN SELAMA COVID-19
}

\author{
Pebri Hastuti $^{1}$, La Ane ${ }^{1}$, Melati Yahya ${ }^{1}$ \\ Korespondensi: pebrihastuti06@gmail.com, laane@unimed.ac.id, melati.yahya@yahoo.com \\ ${ }^{1}$ Pendidikan ekonomi, Universitas Negeri Medan
}

\begin{abstract}
The COVID-19 pandemic was first announced by the government on March 2, 2020. COVID-19 has caused many impacts on various economic sectors in Indonesia. Not only in Indonesia but the impact of Covid-19 has disrupted world economic chains. In fact, it has the potential to cause an economic crisis in a number of countries if it is not dealt with quickly and appropriately. Especially in the exchange rate of the rupiah against the United States of America (US) which is increasingly weakening. This study aims to determine differences in the rupiah exchange rate before and during the co-19. The author uses library research instruments, documentation studies, internet browsing, where the data taken is secondary data from relevant agencies obtained from Bank Indonesia publications through Jakarta Interbank Spot Dollar Rate (Jisdor) data, data obtained from Jisdor is the rupiah exchange rate against the US dollar. This study uses quantitative methods with data analysis tools used are different test methods namely Wilcoxon Test with the help of the computer program SPSS Version 21. Where the data is taken from 7 November 2019 to 28 February 2020 before Covid-19 and during Covid-19 on March 2 until June 30, 2020. The method aims to find out significant differences between the rupiah exchange rates before and during the pandemic. The results of data processing showed that there were significant differences between the rupiah exchange rates before and during the pandemic. So it can be concluded that the spread of Covid-19 in the community will further weaken the exchange rate of the rupiah against the US Dollar.
\end{abstract}

Keyword: Covid pandemic 19, rupiah exchange rate, monetary policy 


\section{PENDAHULUAN}

Hampir seluruh negara di dunia ini sedang mengalami krisis diakibatkan oleh adanya pandemic Covid-19. Dampak dari pandemi ini tidak hanya menyerang dibidang kesehatan namun hamper seluruh lini kehidupan manusia terganggu karenanya. Sejak diumumkan pasien pertama yang tererang Coronaviruses (Covid-19) oleh presiden 2 Maret 2020 lalu, perkembangan serangan virus ini makin bertambah setiap harinya hingga kini. Walaupun begitu, kita tidak boleh mengecilkan bertambahnya pasien sembuh setiap harinya. Berdasarkan informasi yang diperoleh melalui website resmi gugus tugas percepatan penanganan Covid-19 Indonesia per tanggal 30 Juni 2020 telah terkonfirmasi sebanyak $56.386+1.293$ kasus Covid-19, 28.703 pasien dalam perawatan 24.806 pasien sembuh dan sebanyak 2.876 orang pasien meninggal dunia dengan jumlah Orang Dalam Pantauan (ODP) sebanyak 43.797 orang dan Pasien Dalam Pengawasan (PDP) sebanyak 13.182 orang. Untuk lebih jelasnya berikut diuraikan perkembangan kasus peresebaran Covid-19 mulai dari awal bulan Maret hingga akhir Juni

2020.

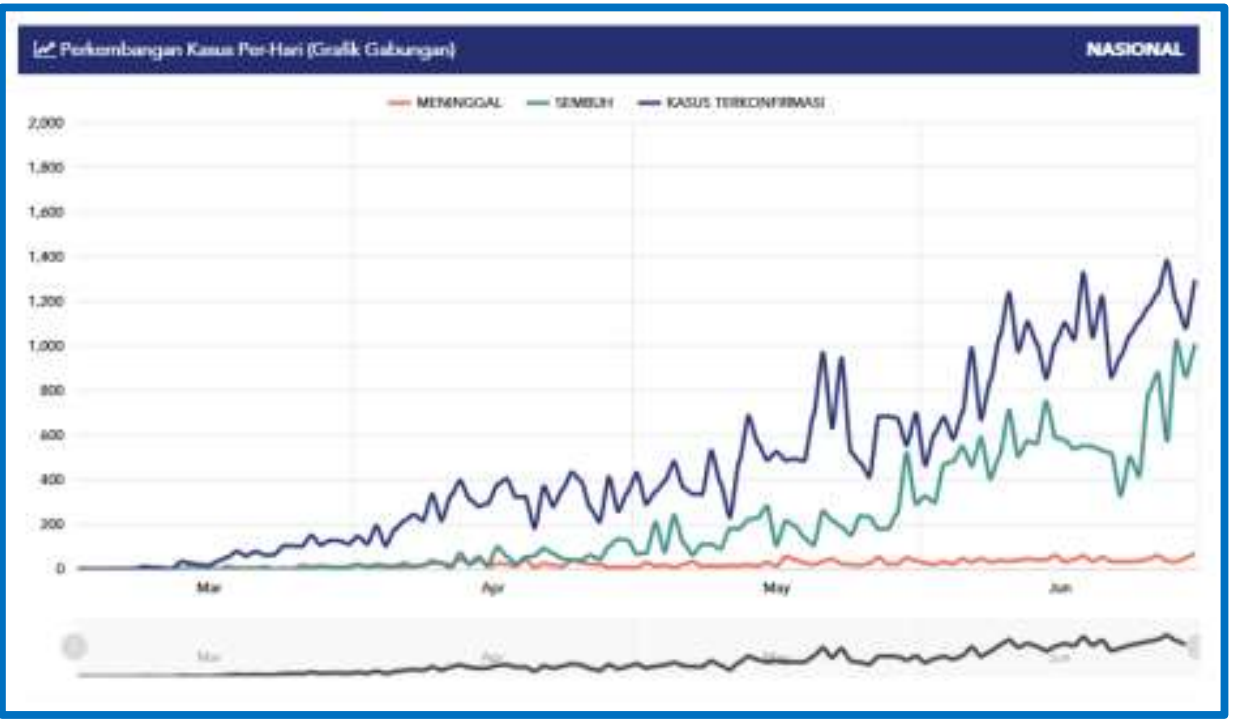

Gambar 1. Perkembangan Kasus Per-Hari Maret-Juni 2020

Berdasarkan Gambar 1 dapat diperoleh informasi bahwa dalam per-Harinya jumlah kasus terkonfirmasi bertambah cukup signifikan. Hal ini tampakmelalui grafik yang bergerak naik mulai dari awal Maret hingga Juni 2020. Pertambahan jumlah kasus terkonfirmasi ini bias disebabkan oleh jumlah Rapid Test yang sudah menyebar di masyarakat sehingga kasus terkonfirmasi yang mulanya tidak terdeksi menjadi terdeteksi. Rendahnya kemampuan masyarakat dalam menjalankan gaya hidup bersih dengan rajin mencuci tangan dengan benar dan disiplin dalam penggunaan masker.
Menurut Azizah (2020) World Health Organization (WHO) menjelaskan bahwa Coronaviruses (Cov) adalah virus yang menginfeksi sistem pernapasan. Infeksi virus ini disebut COVID-19. Virus Corona menyebabkan penyakit flu biasa sampai penyakit yang lebih parah seperti Sindrom Pernafasan Timur Tengah (MERS-CoV) dan Sindrom Pernafasan Akut Parah (SARSCoV). Virus Corona adalah zoonotic yang artinya ditularkan antara hewan dan manusia. Berdasarkan Kementerian Kesehatan Indonesia, perkembangan kasus COVID-19 di Wuhan berawal pada tanggal 30 Desember 2019. Penyebaran virus Corona ini sangat cepat bahkan sampai ke lintas Negara bahkan 
sampai ke Indonesia. Sebagai tanggapan terhadap pandemi ini, beberapa wilayah telah memberlakukan pembatasan sosial berskala besar (PSBB). Pemerintah kini telah mewajibkan pemakaian masker, dan juga social distancing dan work from home. Setelah Virus Covid-19 masuk negara Indonesia, nampaknya berimbas pada semua sektor terutama ekonomi dan telah mengganggu mata rantai ekonomi dunia. Menurut Nabila (2020) hal ini akan berimplikasi buruk bagi perekonomian dunia dan Indonesia pada tahun ini, karena terjadi bersamaan dengan menurunnya harga komoditas dan gejolak pasar keuangan. Bank Dunia memproyeksikan pertumbuhan ekonomi Indonesia di tahun ini akan tertekan di level 2,1 persen. Hal ini disebabkan oleh terus meluasnya persebaran Covid-19 baik di dalam negeri maupun luar negeri. Bahkan, berpotensi menimbulkan krisis ekonomi di sejumlah negara jika tidak ditangani dengan cepat dan tepat. Khususnya pada nilai tukar rupiah terhadap dollar Amerika Serikat (AS) yang semakin hari semakin melemah.

Menurut Kencana (2020) penyebab melemahnya rupiah terhadap dollar AS pada situasi ini, Direktur PT TRFX Garuda Berjangka Ibrahim Assuaibi mengatakan bahwa kurs rupiah akan terus berada di posisi yang rentan karena adanya kepanikan pasar global yang disebabkan oleh penyebaran wabah virus corona. Jadi dengan melonjaknya harga pasar yang terjadi di Indonesia saat ini disebabkan oleh naiknya harga dolar, dimana pada saat ini melonjaknya semua harga bahan pokok yang mengakibatkan resahnya para masyarakat Indonesia dan akibatnya terjadi panic buying sehingga akan semakin memperburuk keadaan. Menurut Mulyani (2020) pakar ekonomi dari Universitas Sebelas Maret (UNS) Surakarta menyoroti lemahnya nilai tukar rupiah terhadap dolar Amerika Serikat, sebagai akibat pandemi Covid-19. Nilai rupiah saat ini sudah menyentuh angka
Rp16.000, dan menjadi yang terlemah dalam kurun waktu 5 tahun terakhir.

Bank Indonesia berupaya menjaga stabilitas rupiah dan terus melakukan strategi bauran demi mendukung keseimbangan perekonomian nasional di tengah pandemi Covid-19. Pandemi ini kemungkinan berlangsung lama. Dalam menjaga keseimbangan kurs rupiah memang tidak mudah. Masalahnya bukan hanya saat terlalu rendah, tapi juga ketika nilai rupiah bisa terlalu tinggi (over-valued) terhadap mata uang lain. Ini bergantung pada situasi yang dihadapi dan sistem nilai tukar yang diterapkan.

Berdasarkan uraian diatas, maka penulis tertarik mengadakan penelitian tentang bagaimana analisis perbedaan kurs rupiah sebelum terjadi pandemi Covid-19 pada tanggal 7 November 2019 hingga 28 Februari 2020 dan kurs rupiah selama terjadi pandemi Covid-19 pada tanggal 2 maret hingga 30 Juni 2020.

\section{TINJAUAN PUSTAKA}

\section{Definisi Kurs}

Menurut Salvatore (2004:140), Kurs adalah Jumlah atau harga mata uang domestic dari mata uang luar negeri (Asing). Secara garis besar teori nilai tukar dapat dibagi yaitu teori persamaan umum dan teori persamaan berdasarkan demand dan supply. Menurut Yoopi (2004: 36) nilai tukar atau kurs (foreign exchange rate) adalah harga mata uang suatu negara relative terhadap mata uang negara lain. Karena nilai tukar ini mencakup dua mata uang, maka titik keseimbangannya ditentukan oleh sisi penawaran dan permintaan dari kedua mata uang tersebut. Dikemukakan lagi oleh Salvatore nilai tukar adalah harga suatu mata uang terhadap mata uang lainnya, atau nilai dari suatu mata uang terhadap mata uang lainnya. Menurut Rita dan Eugene dalam Hilda (2004:27) daya beli suatu mata uang adalah Nilai mata uang suatu Negara di tentukan oleh nilai barang dan jasa yang 
dapat dibeli dengan satu unit mata uang (kebalikan dari tingkat harga).

Informasi yang melebihi satu unit mata uang, maka tingkat pertukaran antar dua mata uang dapat menghasilkan daya beli yang sama antara kedua mata uang tersebut, Kondisi ini disebut daya beli yang tidak nyata. Kedua Negara tersebut akan saling menyesuaikan hingga jual beli benar benar terjadi. Kurs (exchange rate) suatu mata uang adalah nilai tukar atau harganya jika ditukar dengan mata uang yang lain. Sama halnya dengan harga-harga lain dalam ekonomi yang ditentukan oleh interaksi pembeli dan penjual, kurs terbentuk oleh interaksi pembeli dan penjual valas untuk keperluan transaksi internasional.

\section{Bentuk Nilai Tukar}

Sistem nilai tukar sangat tergantung pada kebijakan moneter suatu negara. Bentuk sistem nilai tukar dapat dibagi dalam dua bentuk (Berlianta, 2004), yaitu:

a. Fixed Exchange Rate System

Merupakan suatu sistem nilai tukar dimana nilai suatu mata uang yang dipertahankan pada tingkat tertentu terhadap mata uang asing. Dan bila tingkat nilai tukar tersebut bergerak terlalu besar maka pemerintah melakukan intervensi untuk mengembalikannya. Sistem ini mulai diterapkan pada pasca perang dunia kedua yang ditandai dengan digelarnya konferensi mengenai sistem nilai tukar yang diadakan di Bretton Woods, New Hampshire pada tahun 1944.

b. Floating Exchange Rate System

Setelah runtuhnya Fixed Exchange Rate System maka timbul konsep baru yaitu Floating Exchange Rate System. Dalam konsep ini nilai tukar valuta dibiarkan bergerak bebas. Nilai tukar valuta ditentukan oleh kekuatan permintaan dan penawaran valuta tersebut di pasar uang.

Fakta yang terjadi di banyak negara di dunia menganut varian dari kedua sistem pokok nilai tukar diatas. Menurut Gilis, dalam Yoopi (2004), terdapat enam sistem nilai tukar berdasarkan pada besarnya intervensi dan candangan devisa yang dimiliki bank sentral suatu negara yang dipakai oleh banyak negara di dunia antara lain:

a. Sistem Nilai Tukar Tetap (fixed exchange rate)

Dalam sistem ini otoritas moneter selalu mengintervensi pasar untuk mempertahankan nilai tukar mata uang sendiri terhadap satu mata uang asing tertentu. Intervensi tersebut memerlukan cadangan devisa yang relatif besar. Tekanan terhadap nilai tukar valuta asing, yang biasanya bersumber dari defisit neraca perdagangan,cenderung menghasilkan kebijakan devaluasi.

b. Sistem Nilai Mengambang Bebas (free floating exchange rate)

Sistem ini berada pada kutub yang bertentangan dengan sistem fixed. Dalam sistem ini, otoritas moneter secara teoritis tidak perlu mengintervensi pasar sehingga sistem ini tidak memerlukan cadangan devisa yang besar. Sistem ini berlaku di Indonesia saat ini.

c. Sistem Wider Band

Pada sistem tersebut nilai tukar dibiarkan mengambang atau berfluktuasi diantara dua titik, tertinggi dan terendah. Apabila keadaan perekonomian mengakibatkan nilai tukar bergerak melampaui batas tertinggi dan terendah tersebut, maka otoritas moneter akan melaksanakan intervensi dengan cara membeli atau menjual rupiah sehingga nilai tukar rupiah berada diantara kedua titik yang telah ditentukan.

d. Sistem Mengambang Terkendali (Managed Float)

Dalam sistem ini, otoritas moneter tidak menentukan untuk mempertahankan satu nilai tukar tertentu. Namun, otoritas moneter secara berkelanjutan melaksanakan intervensi berdasarkan 
pertimbangan tertentu, misalnya cadangan devisa yang menipis. Untuk mendorong ekspor, otoritas moneter akan melakukan intervensi agar nilai mata uang menguat.

e. Sistem Crawling Peg

Otoritas moneter dalam sistem ini mengaitkan mata uang domestik dengan beberapa mata uang asing.Nilai tukar tersebut secara periodik dirubah secara berangsur-angsur dalam persentase yang kecil.Sistem ini dipakai di Indonesia pada periode 1988-1995.

f. Sistem Adjustable Peg

Dalam sistem ini, otoritas moneter selain berkomitmen untuk mempertahankan nilai tukar juga berhak untuk merubah nilai tukar apabila terjadi perubahan dalam kebijakan ekonomi.

\section{Faktor-Faktor yang Mempengaruhi Nilai Tukar}

Menurut Suseno (2004) dalam sistem nilai tukar tetap, mata uang lokal ditetapkan secara tetap terhadap mata uang asing.Sementara dalam sistem nilai tukar mengambang, nilai tukar atau kurs dapat berubah-ubah setiap saat, tergantung pada jumlah penawaran dan permintaan valuta asing relatif terhadap mata uang domestik. Setiap perubahan dalam penawaran dan permintaan dari suatu mata uang akan mempengaruhi nilai tukar mata uang yang bersangkutan.

Dalam hal permintaan terhadap valuta asing relatif terhadap mata uang domestik meningkat, maka nilai mata uang domestik akan menurun. Sebaliknya jika permintaan terhadap valuta asing menurun, maka nilai mata uang domestik meningkat.Sementara itu, jika penawaran valuta asing meningkat relatif terhadap mata uang domestik, maka nilai tukar mata uang domestik meningkat. Sebaliknya jika penawaran menurun, maka nilai tukar mata uang domestik menurun.
Dilihat dari faktor-faktor yang mempengaruhinya, terdapat 3 faktor utama yang mempengaruhi permintaan valuta asing, yaitu:

a. Faktor pembayaran impor

Semakin tinggi impor barang dan jasa, maka semakin besar permintaan terhadap valuta asing sehingga nilai tukar akan cenderung melemah. Sebaliknya, jika impor menurun, maka permintaan valuta asing menurun sehingga mendorong menguatnya nilai tukar.

b. Faktor aliran modal keluar

Semakin besar modal keluar, maka semakin besar permintaan valuta asing dan pada lanjutannya akan melemah nilai tukar uang. Aliran modal keluar meliputi pembayaran hutang penduduk Indonesia (baik swasta dan pemerintah) kepada pihak asing dan penempatan dana penduduk Indonesia ke luar negeri.

c. Kegiatan spekulasi

Semakin banyak kegiatan spekulasi valuta asing yang dilakukan oleh spekulannnnn maka semakin besar nilai permintaan terhadap valuta asing sehingga memperlemah nilai tukar mata uang lokal terhadap mata uang asing.

\section{METODE PENELITIAN}

Jenis penelitian ini adalah penelitian komparatif. Menurut Nazir (2005: 58) penelitian komparatif adalah sejenis penelitian deskriptif yang ingin mencari jawaban secara mendasar tentang sebabakibat, dengan menganalisis faktor-faktor penyebab terjadinya ataupun munculnya suatu fenomena tertentu. Jadi, Penelitian komparatif merupakan penelitian yang bersifat membandingkan antara dua kelompok atau lebih dari suatu variabel tertentu. Penelitian ini dilakukan untuk membandingkan persamaan dan perbedaan dua atau lebih fakta-fakta dan sifat-sifat objek yang di teliti berdasarkan kerangka pemikiran tertentu. Pembahasan dalam penelitian ini adalah menganalisis kurs 
rupiah sebelum dan sesudah terjadi pandemi Covid-19 di indonesia pada tanggal 7 November 2019 sampai 28 Februari 2020 dan setelah terjadi penyebaran virus corona pada tanggal 2 maret sampai 30 Juni 2020, yang bertujuan untuk mengetahui perbedaan antara variabel satu dengan variabel yang lainnya.

Penelitian ini menggunakan data sekunder dengan deret waktu harian (time series) pada tanggal 7 November 2019 hingga 28 Februari 2020 dan selama terjadi pandemi Covid-19 pada tanggal 2 maret sampai 30 Juni 2020 sesuai dengan data yang disajikan secara riil melalui website resmi Bank Indonesia. Data penelitian penulis peroleh dari publikasi Bank Indonesia melalui data Jakarta Interbank Spot Dollar Rate (Jisdor). Selain itu diperoleh dari, jurnal, website yang relevan serta buletinbuletin penelitian dan hal-hal lain yang mendukung penelitian ini.
Data yang diperoleh kemudian di analisis menggunakan uji beda yaitu $U j i$ Wilcoxon dengan menggunakan bantuan program komputer SPSS Versi 21. Data yang dianalisis tersebut akan memperoleh nilai $p$ value yang berguna untuk menentukan hipotesis akan diterima atau ditolak. Dengan kriteria pengambilan keputusan sebagai berikut:

1. Ha diterima : Jika nilai Asymp.Sig.(2tailed) lebih kecil dari $<0,05$

2. Ha ditolak : Jika nilai Asymp.Sig.(2tailed) lebih kecil dari $>0,05$

\section{HASIL DAN PEMBAHASAN}

\section{Deskripsi data}

Berikut tersaji data yang di peroleh dari publikasi melalui website resmi Bank Indonesia menggunakan data Jakarta Interbank Spot Dollar Rate (Jisdor) dalam bentuk grafik sebagai berikut:

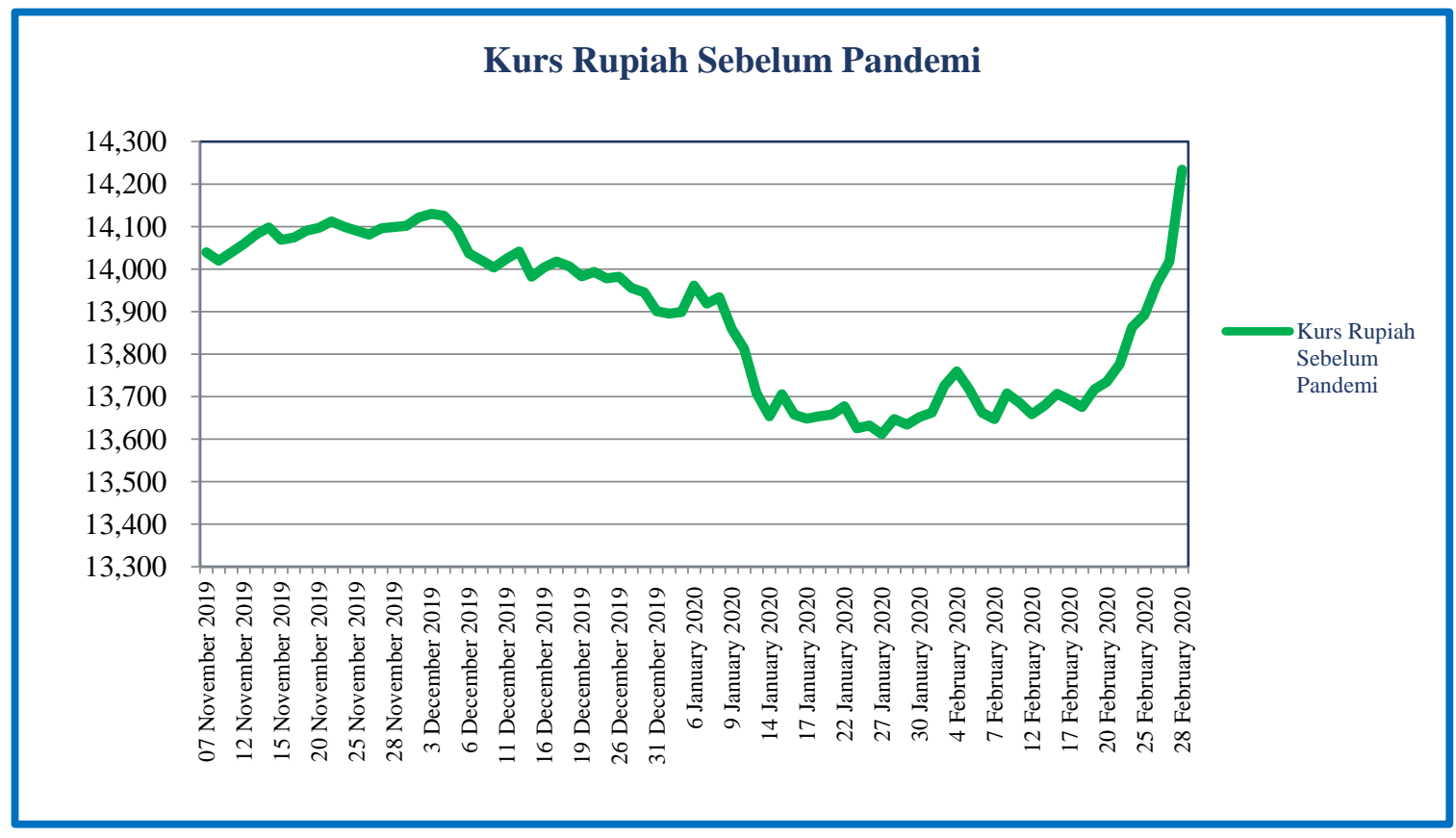

Gambar 2. Kurs Rupiah Sebelum Covid-19

Melalui grafik pada Gambar 2 di atas data dilihat bagaimana pergerakan rupiah selama kurun waktu 7 november 2019 hingga 28 Februari 2020 dimana waktu tersebut merupakan masa sebelum diumumkannya pasien pertama yang terkena dampak Covid19. Sepanjang November 2019 kurs rupiah bergerak pada kisaran Rp.14.000 yang 
kemudian bergerak menguat terhadap Dollar Amerika di bulan Januari 2020 yang bergerak pada kisaran Rp.13.000. Melewati pertengahan bulan Februari 2020 rupiah kembali melemah hingga akhir Februari
2020. Hal ini terjadi dikarenakan sudah merebaknya isu adanya masyarakat yang terdampak coronaviruses, meskipun belum ada statement dari kementerian kesehatan.

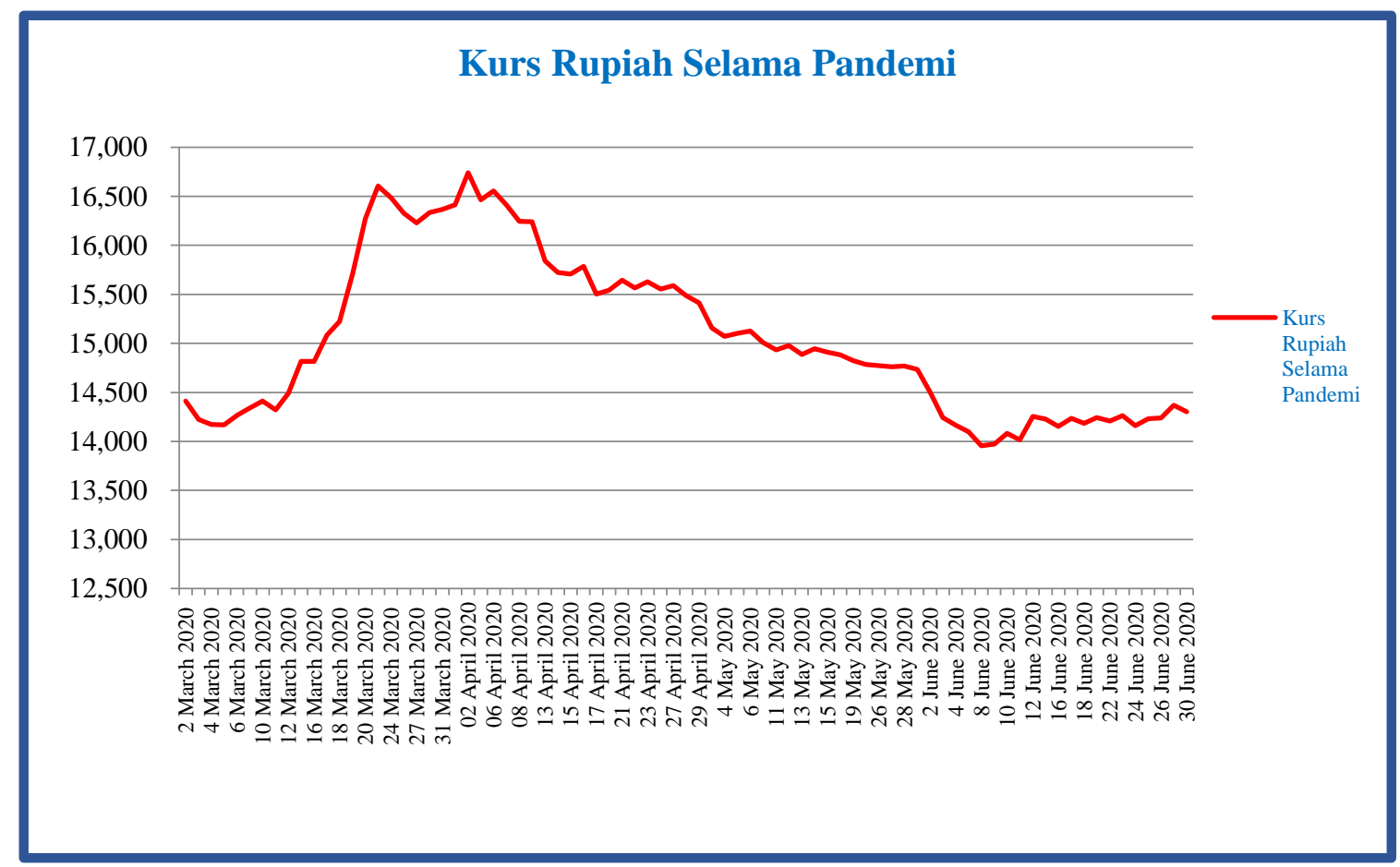

Gambar 3. Kurs Rupiah Selama Covid-19

Menilik melalui grafik pada Gambar 3 di atas, dapat kita ketahui bahwa mulai dari 2 Maret 2020 yaitu hari dimana diumumkannya kasus pasien pertama Covid19 kurs rupiah melemah hingga puncaknya sekitar tanggal 2 April 2020 rupiah berada pada titik terlemahnya menyentuh angka Rp. 16.741,- untuk satu dollar Amerika. Hal ini dapat terjadi karena adanya keraguan oleh para pelaku bisnis dan ekonomi di Indonesia tentang kemampuan pemerintah Indonesia dalam menangai Covid-19. Hal senada dikemukakan oleh Hanggoro (2020) yang menyatakan "nilai tukar rupiah terhadap dolar Amerika Serikat sempat jatuh dari tingkat Rp13.000-an ke Rp16.000-an per dolar AS selama minggu terakhir Maret 2020, pelemahan ini berkait dengan sikap pesimistis pelaku bisnis dan ekonomi terhadap kebijakan pemerintah Indonesia dalam menangani Covid-19". Dalam mengatasi hal tersebut pemerintah berupaya untuk meyakinkan kembali pelaku bisnis dan ekonomi, dengan cara mengeluarkan berbagai stimulus ekonomi, yang kemudian diperkuat oleh Bank Indonesia dengan kebijakan di bidang moneter untuk memperkuat rupiah. Hasilnya, rupiah menguat kembali pada perdagangan Senin, 13 April 2020.

\section{Uji Wilcoxon}

Selanjutnya data tersebut diolah menggunakan Uji Wilcoxon dengan menggunakan SPSS Versi 21. Berdasarkan hasil uji diperoleh hasil sebagai berikut: 
Tabel 1. Ranks

NIAGAWAN Vol 9 No 3 November 2020

\begin{tabular}{|ll|r|r|r|}
\hline & N & Mean Rank & Sum of Ranks \\
\hline \multirow{5}{*}{ Selama - Sebelum } & Negative Ranks & $0^{\mathrm{a}}$ &, 00 &, 00 \\
& Positive Ranks & $79^{\mathrm{b}}$ & 40,00 & 3160,00 \\
& Ties & $0^{\mathrm{c}}$ & & \\
& Total & 79 & & \\
\hline
\end{tabular}

a. Selama $<$ Sebelum

b. Selama $>$ Sebelum

c. Selama $=$ Sebelum

Berdasarkan hasil olahan data pada Tabel 1 diketahui bahwa negative ranks atau selisih (negatif) antara data kurs rupiah sebelum dan selama pandemic Covid-19 adalah 0, baik pada nilai N, Mean Rank, maupun Sum Rank. Nilai nol (0) disini menunjukkan bahwa tidak adanya penurunan (pengurangan) nilai kurs rupiah sebelum pandemi ke selama pandemic. Selanjutnya Positive Ranks atau selisih (positif) antara kurs rupiah sebelum pandemic Covid-19 dan selama Covid-19. Dalam baris tersebut diketahui terdapat 79 data positif yang artinya bahwa kurs rupiah mengalami peningkatan dari kondisi sebelum pandemi berlanjut pada kondisi selama pandemic. Dengan rata-rata peningkatan (Mean Rank) sebesar 40,00. Sedangkan jumlah rangking positif atau Sum of Ranks adalah sebesar 3160,00. Lebih lanjut kesamaan (Ties) angka kurs rupiah sebelum dan selama pandemic adalah 0 yang dapat diartikan bahwa tidak ada angka kurs rupiah yang sama antara kondisi sebelum dan selama terjadi pandemi

Tabel 2. Wilcoxon Test Statistics ${ }^{\mathrm{a}}$

\begin{tabular}{|l|r|}
\hline & Setelah - Sebelum \\
\hline$Z$ & $-7,722^{\mathrm{b}}$ \\
Asymp. Sig. (2-tailed) &, 000 \\
\hline
\end{tabular}

a. Wilcoxon Signed Ranks Test

b. Based on negative ranks.

Hasil pengujian hipotesis pada Tabel 2 diketahui bahwa nilai Asymp.Sig. (2-tailed) adalah sebesar $0,000<$ dari 0.05 . Berdasarkan kriteria dapat dikategorikan bahwa "Ha diterima" yang artinya bahwa terdapat perbedaan yang signifikan antara kurs rupiah sebelum terjadi pandemic dengan kurs rupiah selama pandemic berlangsung. Sehingga dapat kita simpulkan bahwa terjadinya pandemic Covid-19 sangat berpengaruh signifikan terhadap pelemahan kurs rupiah terhadap dollar Amerika. Hal ini sejalan dengan pendapat Haryanto dalam sebuah artikel pada Jurnal Bappenas yang menyatakan bahwa Semakin tinggi kasus Covid-19 maka akan semakin besar jumlah rupiah yang harus dikeluarkan untuk mendapatkan satu dollar Amerika (Perencanaan et al., 2020).

\section{Pembahasan}

Berdasarkan hasil analisis tersebut diketahui bahwa terdapat pelemahan kurs rupiah sebagai akibat dari pandemi Covid-19 yang melanda Indonesia. Hal ini senada dengan pendapat hasil survey Bappenas RI yang menyatakan bahwa terjadi fluktuasi 
yang signifikan nilai tukar rupiah sebagai dampak dari terjadinya Covid-19. Hasil analisis terebut menyimpulkan bahwa semakin tinggi kasus Covid-19 maka nilai rupiah akan melemah terhadap Dollar (Perencanaan et al., 2020). Berdasarkan hasil penelitian tersebut dengan didukung oleh hasil analisis dari Bappenas RI dapat kita pahami bahwa dibutuhkan serangkaian kebijakan oleh pemerintah untuk meredam meluasnya dampak dari Covid-19 dan tentunya didukung oleh masyarakat yang mampu dengan disiplin dalam menerapkan protocol kesehatan dalam melaksanakan aktivitas sehari-hari.

Kita sadari bahwa serangan pandemi yang telah melanda Indonesia beberapa bulan terakhir tentunya berdampak sangat signifikan terhadap perekonomian. Upaya untuk memitigasi dampak penyebaran Covid19 telah dilakukan oleh pemerintah maupun Bank Indonesia dengan serangkaian bauran kebijakan baik Fiskal Maupun Moneter. Tanpa upaya yang serius maka dampak dari penyebaran Covid-19 ini akan mendalam dan tentunya merusak segala sendi kehidupan masyarakat. Pernyataan ini diperkuat oleh pernyataan

Bank Indonesia selaku Bank Sentral telah mengeluarkan berbagai jenis kebijakan yang segera dilaksanakan dalam memitigasi pelemahan nilai tukar mata uang Rupiah terhadap mata uang asing. Menurut Haryanto dalam artikel pada Jurnal Bappenas (Perencanaan et al., 2020) menyatakan bahwa ada rangkaian kebijakan yang dilakukan Bank Indonesia dalam memitigasi pelemahan nilai tukar Rupiah diantaranya sebagai berikut:

a. Intervensi Cadangan Devisa sebesar US\$7 miliar untuk stabilkan mata uang Rupiah. Sementara itu, USD 2,4 miliar dikeluarkan untuk membayar utang pemerintah yang jatuh tempo.

b. Menurunkan suku bunga kebijakan BI7DDR pada Februari dan Maret, masing-masing sebesar 25bps, c. Meningkatkan intensitas triple intervention di pasar spot, DNDF, dan pembelian SBN di pasar sekunder,

d. Menurunkan Giro Wajib Minimum (GWM) Valas bank umum konvensional dari semula $8 \%$ menjadi $4 \%$,

e. Memperpanjang tenor repo SBN dan lelang tiap hari untuk memperkuat pelonggaran likuiditas rupiah dan menambah frekuensi lelang FX Swap menjadi setiap hari untuk memastikan kecukupan likuiditas,

f. Memperluas jenis underlying transaksi DNDF sehingga dapat mendorong lindung nilai atas kepemilikan Rupiah di Indonesia

g. Menurunkan GWM Rupiah sebesar 50bps untuk bank yang melakukan kegiatan ekspor-impor, pembiayaan kepada UMKM dan/atau sektor prioritas lain,

h. Melonggarkan ketentuan Rasio Intermediasi Makroprudensial (RIM),

i. Menyediakan uang higienis, menurunkan biaya SKNBI, penetapan MDR QRIS 0\% untuk merchant usaha mikro, dan mendukung penyaluran dana non-tunai program-program pemerintah seperti Program Bantuan Sosial PKH dan BNPT, Program Kartu Prakerja, dan Kartu Indonesia Pintar.

j. Melakukan intervensi pasar dengan surat utang berdenominasi dolar Amerika Serikat (AS) sebesar USD4,3 miliar. Penerbitan surat berharga global ini dilakukan dalam tiga bentuk yaitu Surat Berharga Negara (SBN) seri RI1030, RI 1050, dan RI 0470.

Rangkaian kebijakan tersebut merupakan respon cepat Bank Indonesia dalam upaya memitigasi pelemahan nilai tukar rupiah akibat adanya Covid-19. Tentunya upaya tersebut harus dilakukan secara komprehensif oleh Bank Indonesia diiringi dengan kesadaran masyarakat agar senantiasa menjaga kedisiplinan dalam menerapkan protocol kesehatan terutama 
dalam penerapan kebijakan New Normal saat ini. Seluruh bauran kebijakan ini dilaksanakan dengan harapan bahwa tidak ada lagi masyarakat yang terdampak Coronaviruses dan penyebarannya dapat diperkecil.

\section{KESIMPULAN DAN SARAN}

Berdasarkan hasil pengolahan data diperoleh hasil bahwa terdapat perbedaan yang cukup signifikan antara nilai kurs rupiah sebelum dan selama terjadi pandemic Covid-19. Sehingga dapat disimpulkan bahwa terjadinya pandemi Covid-19 berdampak signifikan terhadap pelemahan nilai tukar rupiah terhadap mata uang asing dalam hal ini adalah Dollar Amerika. Diperlukan upaya pemerintah maupun Bank Indonesi adalam memitigasi pelemahan nilai tukar tersebut dengan serangkaian bauran kebijakan yang harus segera direalisasikan. Karena pengunduran dalam mengambil keputusan dalam mengatasi bencana nasional ini akan menimbulkan dampak jangka panjang dan meluas di berbagai sendi kehidupan berbangsa.

\section{REFERENSI}

Anonim. 2020. Peta Sebaran (Perkembangan Kasus Per-Hari). https://covid19.go.id/peta-sebaran.

Diakses tanggal 1 Juli 2020.

Azizah, Muftiyatul. 2020. Dampak Virus

Corona Terhadap Perekonomian Global Khususnya Di Indonesia. https://duta.co/dampak-virus-coronaterhadap-perekonomian-global-

khususnya-di-indonesia. Diakses pada 27 April 2020.

Berlianta, Heli Charisma. 2004. Mengenal Valuta Asing. Yogyakarta: Gadjah Mada University Press.

Hanggoro, Hendaru Tri. 2020. Sejarah Nilai Tukar Rupiah terhadap Dolar AS. https://historia.id/ekonomi/articles/seja rah-nilai-tukar-rupiah-terhadap-dolarsv22W3. diakses pada 30 April 2020.
Hilda. 2004. Pengaruh Likuiditas, Kurs, Suku Bunga Deposito, dan Volume Perdagangan terhadap Harga Saham Perusahaan Manufaktur di BEJ. Skripsi: Universitas Riau

Kencana, Maulandy Rizki Bayu. 2020.

Kepanikan Pasar Akibat Corona

Bikin Rupiah Tembus Rp 16 Ribu. https://www.liputan6.com/bisnis/read/ 4206960/kepanikan-pasar-akibatcorona-bikin-rupiah-tembus-rp-16ribu\#. Diakses pada 30 April 2020

Mulyani, Devi Sri. 2020. Ekonom UNS:

Nilai Tukar Rupiah Anjlok Akibat Covid-19

https://ekonomi.bisnis.com/read/20200

321/9/1216304/ekonom-uns-nilai-

tukar-Rupiah-anjlok-akibat-Covid-19-

. diakses pada 27 April 2020.

Nabila, Nurul Putri. 2020. Dampak

Pandemi Corona Terhadap Sektor Ekonomi Indonesia.

https://sukabumiupdate.com/detail/bale -warga/opini/67504-DampakPandemi-Corona-Terhadap-SektorEkonomi-Indonesia. diakses pada 28 April 2020.

Nazir, Moh. 2005. Metode Penelitian. Jakarta: Ghalia Indonesia.

Perencanaan, K., Nasional, P., \& Indonesia, B. R. (2020). Dampak Covid-19 terhadap Pergerakan Nilai Tukar Rupiah dan Indeks Harga Saham Gabungan (IHSG). Jurnal Perencanaan Pembangunan: The Indonesian Journal of Development Planning, 4(2), 151165.

https://doi.org/10.36574/jpp.v4i2.114

Prayogo, Cahyo. 2020. 5 Jurus BI Stabilkan

Nilai Tukar Rupiah di Tengah

Pandemi.

https://www.wartaekonomi.co.id/read28 0638/5-jurus-bi-stabilkan-nilai-tukarrupiah-di-tengah-pandemi. diakses pada 1 Mei 2020 
Salvatore, Domonick. 2004. Ekonomi Moneter. Penerbit Erlangga, Jakarta

Suseno, Iskandar Simorangkir. 2004. Sistem Kebijakan Nilai Tukar. Jakarta: Bank Indonesia.
Yoopi Abimanyu. 2004. Memahami Kurs Valuta Asing. Jakarta: FE-UI. 